\title{
PENDAMPINGAN PENGGUNAAN MEDIA SOSIAL YANG CERDAS DAN BIJAK BERDASARKAN UNDANG-UNDANG INFORMASI DAN TRANSAKSI ELEKTRONIK
}

\author{
Siti Nurul Intan Sari D12, Sylvana Murni D HUTABARAT22 \\ Fakultas Hukum, UPN Veteran Jakarta \\ Email: sinuinsada@yahoo.com
}

\begin{abstract}
Humans as social beings are inseparable from interacting and communicating with other humans. Development of technology, make development the way of interaction humans being with social media. Social media as an alternative communication media for community to decrease the distance and the time is popular from children until adults especially housewives

Problems with the use of social media among houswives who have been ensnared by legal cases have occurred alot, this can be seen from several cases both in print and other media. Therefore, the servants carry out cunselling and assistance to housewives in the service team partners RT.005, Kelurahan Ciganjur, Kecamatan Jagakarsa, Jakarta Selata, to change the understandings of housewives in using social media intelligently and wisely based on Rules of Electronic Information and Transactions. The participation of the partner in this service to providethe tools and information needed for the service to make well.

The method of this assistance used communication and dialogues with the target community throught extension activities and finally a simulation activity is caried out to the test increase in participant understanding. This community service provides results in the form of increased knowledge and understanding of participants, namely housewives about the use of wise and intelligent social media in their daily lives based on the information and electronic transaction act so that the use of social media can provide benefits rather than bring their users caught in legal cases.
\end{abstract}

Keywords: Sosial Media, Smart, Rules Of Electronic Information and Transactions

\section{ABSTRAK}

Manusia sebagai makhluk sosial tidak terlepas dari berinteraksi dan berkomunikasi dengan manusia lainnya. Seiring berkembangnya teknologi, maka berkembang pula cara manusia berinteraksi dengan manusia lainnya, salah satu cara berkomunikasi yang sangat digemari saat ini adalah dengan menggunakan media sosial. Media sosial sebagai media komunikasi alternatif bagi masyarakat untuk mempersingkat jarak dan waktu mulai digemari dari kalangan anak-anak hingga orang dewasa khususnya ibu rumah tangga.

Permasalahan Penggunaan Media Sosial di kalangan ibu rumah tangga yang terjerat kasus hukum sudah banyak terjadi, hal ini terlihat dari beberapa kasus baik di media cetak maupun media lainnya. Oleh karena itu, pengabdi melaksanakan penyuuhan dan pendampingan pada ibu rumah tangga di mitra tim pengabdi yaitu RT. 005, Kelurahan Ciganjur, Kecamatan Jagakarsa, Jakarta Selatan,untuk merubah pemahaman ibu rumah tangga dalam menggunakan media sosial secara cerdas dan bijak berdasarkan Undang-Undang Informasi Dan Transaksi Elektronik. Adapun partisipasi mitra dalam 
pengabdian ini adalah dengan menyediakan sarana dan data yang diperlukan agar pelaksanaan pengabdian dapat berjalan lancar.

Metode yang digunakan dalam pelaksanaan Pengabdian Kepada Masyarakat ini dilakukan dengan metode pendampingan, melalui proses berdialog dengan masyarakat sasaran melalui kegiatan penyuluhan dan pada akhirnya dilaksanakan kegiatan simulasi untuk menguji peningkatan pemahaman peserta. Pengabdian masyarakat ini memberikan hasil berupa meningkatnya pengetahuan dan pemahaman peserta yaitu ibu rumah tangga mengenai penggunaan media sosial yang bijak dan cerdas dalam kehidupan sehari-hari berdasarkan Undang-Undang Informasi dan Transaksi Elektronik agar penggunaan media sosial dapat memberikan manfaat bukan membawa penggunanya terjerat ke kasus hukum.

Kata Kunci : Media Sosial, Cerdas, Undang-Undang Informasi dan Transaksi Elektronik

\section{PENDAHULUAN}

Manusia sebagai makhluk sosial tidak terlepas dari berinteraksi dan berkomunikasi dengan manusia lainwives nya. Hal inilah yang menuntut teknologi terus berupaya menciptakan komunikasi dan interaksi yang cepat dan mudah. Kehadiran teknologi khususnya internet membawa banyak dampak perubahan bagi kehidupan manusia saat ini, salah satunya dengan adanya media sosial.

Media Sosial adalah media online (daring) yang dimanfaatkan sebagai sarana pergaulan sosial secara online di internet. Di media sosial, para penggunanya dapat saling berkomunikasi, berinteraksi, berbagi, networking, dan berbagai kegiatan lainnya. Adapun jenis media sosial yang ada saat ini adalah youtube, facebook, twitter, instagram, whatsapp dan media sosial lainnya.

Saat teknologi internet dan mobile phone makin maju maka media sosial pun ikut tumbuh dengan pesat. Kini untuk mengakses facebook atau twitter misalnya, bisa dilakukan dimana saja dan kapan saja hanya dengan menggunakan sebuah mobile phone. Demikian cepatnya orang bisa mengakses media sosial mengakibatkan terjadinya fenomena besar terhadap arus informasi tidak hanya di negara-negara maju, tetapi juga di Indonesia. Karena kecepatannya media sosial juga mulai tampak menggantikan peranan media massa konvensional dalam menyebarkan berita-berita.

Media sosial sebagai media komunikasi alternatif bagi masyarakat untuk mempersingkat jarak dan waktu mulai digemari dari kalangan anak-anak hingga orang dewasa. Tidak dapat dipungkiri, bahwa keberadaan media sosial tidak bias terlepas dari kehidupan saat ini,

Penggunaan media sosial akan menjadi persoalan hukum bagi dirinya sendiri, apabila tidak dimanfaatkan sebagai mestinya. Penggunaan media sosial yang tidak sebagimana mestinya akan menjadi boomerang bagi penggunanya yang akan membawanya terjerat ke kasus hukum.

Awal November 2018, unggahan status Facebook Fetniarti seorang ibu rumah tangga di Berdasarkan kesimpulan penyelidikan polisi, unggahan status Fetniarti adalah kabar bohong alias hoaks. Fetniarti dijerat dengan Pasal 45A ayat (1) Undang-Undang Nomor 19 Tahun 2016 tentang Perubahan atas Undang-Undang Nomor 11 Tahun 2008 tentang Informasi dan Transaksi Elektronik (ITE) dengan ancaman pidana paling lama enam tahun atau denda paling banyak Rp1 miliar. Kasus yang menjerat Fetniarti, memang bukan yang dominan, jenis kasus pencemaran nama baik menjadi paling banyak dengan 174 kasus, disusul penyebaran kebencian dengan 41 kasus. Berdasarkan profesi pelaku, status pekerjaan lainnya mencakup ibu rumah tangga, warga, pemuka agama, dan lain-lain--memang paling banyak dilaporkan dengan 97 kasus. Dari seluruh kasus yang dilaporkan ini, 62 di antaranya berasal dari 
unggahan Facebook. Banyaknya ibu rumah tangga terjerat UU ITE boleh jadi menggambarkan satu masalah besar: edukasi tentang jelajah internet yang bijak masih sangat rendah.

Sejak berlakunya Undang-Undang Republik Indonesia Nomor 19 Tahun 2016 Tentang Perubahan Atas Undang-Undang Nomor 11 Tahun 2008 Tentang Informasi Dan Transaksi Elektronik, adanya minimal tiga ancaman yang dapat berpotensi menimpa pengguna media sosial, yaitu:

1. Ancaman pelanggaran kesusilaan (Pasal 27 Ayat 1).

2. Penghinaan dan/atau pencemaran nama baik (Pasal 27 Ayat 3).

3. Penyebaran kebencian berdasarkan suku, agama, ras dan antar golongan (SARA) (Pasal 28 Ayat 2).

Dari uraian diatas, dapat diketahui bahwa adanya ancaman bagi pengguna media sosial, apabila media sosial tidak digunakan secara bijak

Hasil riset We are Social and hootsuite (2017) sebagaimana dilansir linkedlinn mengungkapkan jika masyarakat Indonesia menempati urutan ke empat tersbesar di dunia pengguna media sosial setelah warga Amerika Serikat, India dan Brazil. Di Indonesia 20,4 \% penggunanya adalah wanita dan $24,2 \%$ penggunanya adalah pria. Sisa penggunannya adalah warga masyarakat lainnya. Dari 20,4 persen wanita pengguna, sebesar $65 \%$ nya adalah ibu-ibu rumah tangga sementara pengguna pria sebesar $65 \%$ nya adalah pemuda.

Ibu rumah tangga merupakan kelompok yang rentan terhadap penggunaan media sosial yang tidak sebagaimana mestinya, kebanyakan pengguna media sosial tinggal di kota-kota besar seperti Jakarta. Salah satu pengguna media sosial adalah kalangan ibu rumah tangga yang paling sering berhubungan dengan teknologi informasi.

Salah satu pengguna sosial media di kalangan ibu rumah tangga adalah ibu-ibu rumah tangga di RT.005, Kelurahan Ciganjur, Kecamatan Jagakarsa, Jakarta Selatan. Berdasarkan pengamatan yang dilakukan tim pengabdian, ibu-ibu rumah tangga di RT.005, Kelurahan Ciganjur, Kecamatan Jagakarsa, Jakarta Selatan menggunakan media sosial dalam kehidupan sehari-hari. Oleh karena itu, kami mengadakan kegiatan pengabdian kepada masyarakat kepada ibu rumah tangga yang berjumlah 20 orang dalam bentuk pendampingan dengan judul "Pendampingan Penggunaan Media Sosial Yang Cerdas Dan Bijak Berdasarkan Undang-Undang Informasi Dan Transaksi Elektronik."

\section{METODE PELAKSANAAN}

Sesuai dengan judul Pengabdian Kepada Masyarakat yakni pendampingan, maka metode pelaksanaan Pengabdian Kepada Masyarakat ini dilakukan dengan metode pendampingan. Implementasi riil dari pendampingan dilakukan melalui proses berdialog dengan masyarakat sasaran melalui kegiatan pra penyuluhan, setelah itu ditindaklanjuti dengan kegiatan pelatihan dalam bentuk penyuluhan. Setelah dilakukan sosialisai maka diadakan pula pelatihan penggunaan media sosial yang cerdas dan bijak berdasarkan undang-undang informasi dan transaksi elektronik dan pada akhirnya dilaksanakan kegiatan simulasi untuk menguji peningkatan pemahaman para ibu-ibu rumah tangga untuk menjadi pengguna media sosial yang cerdas dan bijak. Keseluruhan kegiatan dilakukan dengan memperhatikan tertib administratif, sehingga setiap kegiatan wajib mendapatkan izin dan dilakukan pencatatan pada sekretariat Rukun Tetangga setempat yang menjadi mitra dalam pelaksanaan pengabdian masyarakat ini. Secara bertahap, pelaksanaan pengabdian masyarakat dilaksanakan dengan tahap sebagai berikut : 


\section{Tahap Persiapan}

a. Proses perizinan kepada pihak Mitra.

b. Perolehan dan pengumpulan data.

2. Tahap Pelaksanaan (tahap pendampingan melalui sosialisasi, pemyuluhan dan simulasi)

a. Diskusi dengan mitra mengenai peran.

b. Diskusi dengan mitra mengenai solusi.

c. Dialog, diskusi, sosialisasi, dan pelatihan mengenai Penggunaan Media Sosial Yang Cerdas dan Bijak berdasarkan Undang-Undang Informasi Dan Transaksi Elektronik.

3. Tahap Pelaporan

a. Melaporakan kemajuan setelah diadakannya dialog dengan mitra.

b. Mempublikasi hasil Pengabdian Kepada Masyarakat.

c. Melaporkan laporan akhir setelah diseminarkan.

Setiap tahap dilakukan dengan kerja sama tim yang terdiri dari dua orang Dosen Fakultas Hukum UPN "Veteran" Jakarta, sesuai dengan pembagian tugas yang telah disepakatai bersama. Tahap-tahap ini disusun sesuai dengan ketentuan administratif, dan kebutuhan masyarakat yang menjadi target sasaran. Melihat bahwa masyarakat target sasaran merupakan ibu-ibu rumah tangga maka setiap tahap pelaksanaan dilakukan dengan memperhatikan kegiatan atau rutinitas serta latar belakang pengetahuan dan pendidikan dari para ibu rumah tangga tersebut sehingga setiap kegiatan yang terlaksana dihadiri sesuai kuantitas peserta yang ditargetkan.

Dalam tahap persiapan, tim Pengabdian Kepada Masyarakat melakukan kunjungan kepada Ketua RT RT.005, Kelurahan Ciganjur, Kecamatan Jagakarsa, Jakarta Selatan. Hal ini dimaksudkan untuk membangun komunikasi aktif dengan pejabat terkait sehingga setiap proses pengabdian kepada masyarakat yang dilakukan dalam pengetahuan dan izin yang diberikan oleh pihak terkait. Dalam mengurus perizinan, tim Pengabdian Kepada Masyarakat membawa surat tugas dari instansi tim pengabdian masyarakat berasal, disertai denagn permohonan kerja sama melaksanakan kegiatan pengabdian kepada masyarakat. Kegiatan dengan tema ini sangat didukung oleh Ketua RT mengingat tema pengabdian kepada masyarakat ini sangat penting bagi warga mereka. Sesuai dengan ketentuan pelaksanaan pengabdian kepada masyarakat, setiap kegiatan dilakukan dengan proses administrasi dan dokumentasi. Dalam berdialog dengan ketua RT, tim pengabdian kepada masyarakat memulai mencari informasi akurat mengenai jumlah ibu-ibu rumah tangga dan kebiasaan para ibu-ibu rumah tangga dalam menggunakan media sosial. Dalam paparan ketua RT, menguatkan data tim pengabdian kepada masyarakat bahwa pola menggunakan media sosial yang dilakukan ibu-ibu yang menjadi target sasaran memang belum mengetahui adanya ancaman hukuman yang dapat berpotensi menimpa pengguna media sosial apabila tidak digunakan dengan bijak.

Langkah selanjutnya yang dilakukan dalam tahap persiapan adalah pengumpulan data empiris (field research) langsung mengamati pola ibu-ibu rumah tangga di RT.005, Kelurahan Ciganjur, Kecamatan Jagakarsa, Jakarta Selatan dalam menggunakan media sosial yang menjadi target sasaran pengabdian kepada masyarakat. Berdasarkan hasil observasi dan wawancara dengan para ibu-ibu rumah tangga yang menggunakan media sosial, banyak ibu-ibu rumah tangga yang belum mengetahui ancaman hukuman yang dapat berpotensi menimpa pengguna media sosial apabila tidak digunakan dengan bijak dalam Undang-Undang Republik Indonesia Nomor 19 Tahun 2016 Tentang Perubahan Atas Undang-Undang Nomor 11 Tahun 2008 Tentang Informasi Dan Transaksi Elektronik. 
Pada tahap pengumpulan data juga tim menentukan berapa jumlah peserta yang akan diundang dalam proses rangkain pelaksanaan pengabdian kepada masyarakat ini, berdasarkan kajian data mengenai jumlah ibu rumah tangga (wanita yang sudah berkeluarga) dan tidak bekerja, maka tim menentukan jumlah peserta yang diundang sebanyak 20 orang. Terhadap peserta tersbut tim pengabdian kepada masyarakat mempersiapkan materi yang mencakup pengertian media sosial, ciriciri media sosial, kegunaan media sosial, keunggulan media sosial dibanding media konvensional, Undang-Undang Republik Indonesia Nomor 19 Tahun 2016 Tentang Perubahan Atas Undang-Undang Nomor 11 Tahun 2008 Tentang Informasi Dan Transaksi Elektronik (Undang-Undang Informasi dan Transaksi Elektronik),Istilah dalam Undang-Undang Informasi dan Transaksi Elektronik, kasus media sosial yang dibawa ke jalur hukum, ancaman hukuman dalam Undang-Undang Informasi dan Transaksi Elektronik, media sosial dan keluarga, dampak negatif media sosial.

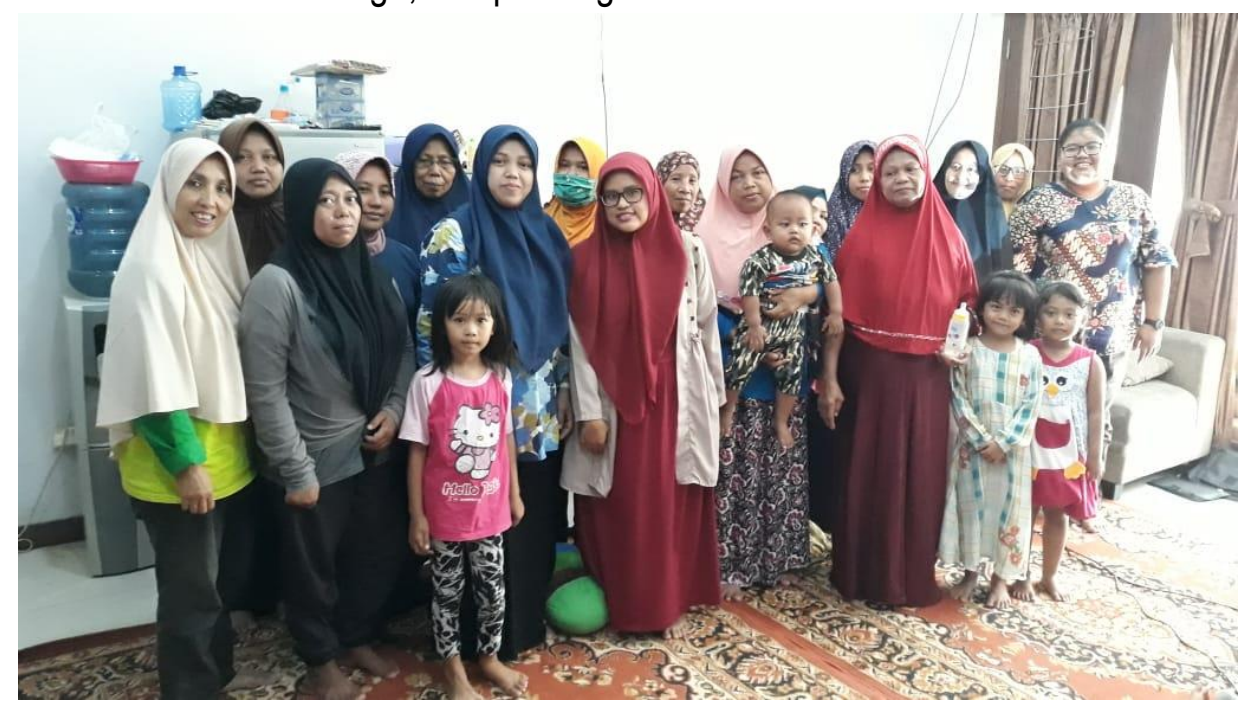

Foto bersama Peserta PKM

Tahap pelaksanaan dilakukan dengan ibu-ibu rumah tangga di RT.005/Kelurahan Ciganjur, Jakarta Selatan dengan dua tahap. Tahap pertama materi yang diberikan difokuskan pada pengertian media sosial, ciri-ciri media sosial, kegunaan media sosial, keunggulan media sosial dibanding media konvensional, media sosial dan keluarga, dampak negatif media sosial. Adapun beberapa materi yang diberikan dalam proses penyuluhan yang diambil dari bahan yang berupa Undang-Undang Republik Indonesia Nomor 19 Tahun 2016 Tentang Perubahan Atas Undang-Undang Nomor 11 Tahun 2008 Tentang Informasi Dan Transaksi Elektronik (Undang-Undang Informasi dan Transaksi Elektronik). Istilah dalam Undang-Undang Informasi dan Transaksi Elektronik, kasus media sosial yang dibawa ke jalur hukum, ancaman hukuman dalam Undang-Undang Informasi dan Transaksi Elektronik, tips menggunakan media sosial yang cerdas dan bijak..

\section{Pengertian Media Sosial.}

Penyajian materi pertama dimulai dengan pengenalan media sosial. Media Sosial (Social Media) adalah saluran atau sarana pergaulan sosial secara online di dunia maya (internet). Para pengguna (user) media sosial berkomunikasi, berinteraksi, saling kirim pesan, dan saling berbagi (sharing), dan membangun jaringan (networking). Pendapat lain mengatakan bahwa media sosial adalah media online yang mendukung interaksi sosial dan media sosial menggunakan teknologi berbasis web yang mengubah komunikasi menjadi dialog interaktif. Interaksi yang 
dilakukan dlam media sosial dapat dilakukan tanpa dibatasi ruang dan waktu karena didukung internet sebagai fasilitas pendukungnya. Jenis media sosial yang ada saat ini adalah YouTube, Facebook, Twitter, Instagram, WhatsApp dan media sosial lainnya.

Ada beberapa keunggulan media sosial antara lain merupakan sebuah alat yang dapat digunakan untuk mempublikasikan diri, pekerjaan, pendapat pribadi, kejadian sehari-hari dari diri sendiri. Bagi perusahaan berarti menambah koneksi atau pun pelanggan dan calon pelanggan. Hal ini disebabkan koneksi berarti potensi untuk meraih pembeli dan selanjutnya dapat berarti potensi meningkatnya pendapatan bagi perusahaan. Selain tiu perusahaan dapat memperoleh informasi. Selain itu juga dalam kemudahan membuat grup dan membentuk komunitas. Dengan media sosial, berkomunikasi secara online dapat dilakukan dengan lebih murah dan mudah dari pada harus bertatap muka. Kemudian kolaborasi dan komunikasi antar wilayah, benua (lintas batas) dapat dimungkinakan dalam media sosial ini, hal tersebut berarti menghilangkan hambatan-hambatan bagi orang-orang yang ingin berhubungan dengan orang lain, tanpa memperhitungkan hambatan jarak, hambatan waktu, hambatan biaya, hambatan sosial budaya, termasuk hambatan gender dan usia. Salah satu bentuk media sosial adalah situs jejaring sosial yang berguna untuk memudahkan pencarian informasi tentang subjek dan objek apapun juga dan dari mana saja.

\section{Ciri-Ciri Media Sosial.}

Ciri-ciri dari media sosial adalah :

a. Konten yang disampaikan dibagikan kepada banyak orang.

b. Isi pesan muncul tanpa penghambat.

c. Konten dapat diterima secara online dalam waktu lebih cepat maupun dijadwalkan.

d. Pengguna medsos adalah kreator dan aktor yang memungkinkan dirinya untuk beraktualisasi diri.

e. Dalam konten medsos terdapat sejumlah aspek fungsional seperti identitas, percakapan (interaksi), berbagi (sharing), kehadiran (eksis), hubungan (relasi), reputasi (status) dan kelompok (group).

\section{Kegunaan Media Sosial.}

Adapun kegunaan dari media sosial :

a. Menghimpun opini publik terhadap suatu kebijakan atau masalah.

b. Mempengaruhi dan memotivasi masyarakat

c. Mudah menyebarkan informasi dengan memanfaatkan saluran informasi yang telah tersedia.

d. Mampu membentuk dan membina hubungan komunikasi di luar batas

e. Mampu menghimpun data, masukan, pendapat dan kritik yang membangun demi kemajuan program pembangunan.

\section{Keunggulan Media Sosial dibanding Media Konvensional.}

Media sosial menjadi salah satu bukti dari kemajuan teknologi yang menantang aturan-aturan yang telah lama dianut oleh media massa konvensional. Media sosial sebagai produk teknologi terbarukan tak hanya memungkinkan penggunanya mengakses informasi tertentu dari media massa, tetapi juga dapat membuat, mencari dan mendistribusikan informasinya secara luas. 
Seiring dengan berkembangnya pengetahuan dan teknologi, media sosial jauh lebih berkembang dibandingkan dengan media konvensional. Keunggulan media sosial dibandingkan media konvensional adalah :

a. Cepat, ringkas, simpel, mudah, padat.

b. Menciptakan hubungan lebih intens dan memberikan kesempatan yang lebih luas kepada user untuk berinteraksi dengan stakeholders.

c. Jangkauan luas dan global.

\section{Dampak Negatif Media Sosial bagi Keluarga.}

Pada materi media sosial dan keluarga, dipaparkan mengenai dampak media sosial bagi hubungan suami istri dan dampak media sosial bagi pada anak. Adapun dampak media sosial bagi hubungan suami istri adalah :

a. Membuat kesepian.

b. Ketidakpuasan hubungan.

c. Pasangan merasa tidak penting.

d. Membanding-bandingkan pasangan.

e. Peluang mencurangi pasangan

Sedangkan dampak negatif media sosial bagi anak adalah :

a) Kesehatan fisik

1) Menatap layar ponsel pintar dan gadget untuk jangka waktu yang lama meningkatkan risiko gangguan mata, seperti miopia dan mata lelah.

2) Anak-anak dapat mengalami kurang tidur dan kurang bisa fokus. Hal ini mengarah pada siklus tidur yang tidak sehat karena anak-anak lebih mengantuk pada siang hari dan kurang tidur di malam hari. Bahkan, jika setiap 15 menit anak menggunakan perangkat pintar, artinya mereka kehilangan 60 menit waktu tidur.

3) Anak-anak yang usianya lebih kecil bisa mengembangkan gangguan keterlambatan bicara yang lebih lama seiring dengan meningkatnya screen time.

4) Anak-anak dapat mengalami berbagai masalah fisik, seperti peningkatan berat badan karena kurang gerak, insomnia, sakit kepala, nutrisi yang buruk, dan masalah penglihatan.

b) Kesehatan mental

1) Bahaya gadget bagi anak dapat menimbulkan masalah kesehatan mental dan perubahan perilaku, hingga depresi.

2) Mereka mungkin juga menjadi agresif dan mudah tersinggung jika orangtua tidak memberi mereka akses menggunakan ponsel atau tablet. Iritabilitas juga akan mempengaruhi keterampilan lainnya, khususnya dalam hal menahan diri, berpikir, dan mengendalikan emosi. Padahal, keterampilan ini membentuk dasar untuk kesuksesan di masa depan.

3) Anak-anak dapat mengembangkan berbagai masalah mental, seperti kecemasan, kesepian, rasa bersalah, isolasi diri, depresi, dan perubahan suasana hati. Paparan terhadap gadget juga dapat meningkatkan risiko ADHD dan autisme pada anak-anak. 


\section{Undang-Undang Republik Indonesia Nomor 19 Tahun 2016 Tentang Perubahan Atas Undang-Undang Nomor 11 Tahun 2008 Tentang Informasi Dan Transaksi Elektronik.}

Undang-Undang Republik Indonesia Nomor 19 Tahun 2016 Tentang Perubahan Atas UndangUndang Nomor 11 Tahun 2008 Tentang Informasi Dan Transaksi Elektronik adalah UndangUndang yang mengatur tentang informasi dan transaksi elektronik salah satunya melalui media sosial yang bertujuan untuk menjamin pengakuan serta penghormatan atas hak dan kebebasan orang lain dan untuk memenuhi tuntutan yang adil sesuai dengan pertimbangan keamanan dan ketertiban umum dalam suatu masyarakat yang demokratis agar terwujud keadilan, ketertiban umum, dan kepastian hokum.

\section{Istilah dalam Undang-Undang Informasi dan Transaksi Elektronik.}

Pada materi yang ini, tim memaparkan berbagai istilah yang ada di dalam Undang-Undang Republik Indonesia Nomor 19 Tahun 2016 Tentang Perubahan Atas Undang-Undang Nomor 11 Tahun 2008 Tentang Informasi Dan Transaksi Elektronik seperti informasi elektronik, transaksi elektronik,dokumen elektronik, tanda tangan elektronik, dan lain-lain.

\section{Kasus Media Sosial yang dibawa ke Jalur Hukum.}

Berikut beberapa kasus hukum yang sempat mencuat karena penggunaan media sosial yang tidak sebagaimana mestinya :

1) Yusniar, warga Makassar Yusniar (27) adalah seorang ibu rumah tangga di Makassar, Sulawesi Selatan. la dijerat karena status Facebook yang diunggahnya pada 14 Maret 2016. Status itu berisi ungkapan kekesalan Yusniar atas kejadian yang menimpa rumah orangtuanya sehari sebelum status tersebut diunggah. la ditahan karena tuduhan pencemaran nama baik melalui media sosial. Yusniar akhirnya divonis bebas.

2) SF, warga Probolinggo SF (22), seorang warga Desa Sukokerto, Kecamatan Pajarakan, Kabupaten Probolinggo, Jawa Timur, ditangkap tim Cyber Polres Probolinggo setelah mengunggah status di akun Facebook bernama Ferdy Damor pada 15 Desember 2017. Status tersebut diunggah setelah ia ditilang polisi karena tidak bisa menunjukkan Surat Izin Mengemudi (SIM). la dijerat Pasal 27 ayat (3) juncto pasal 45 ayat (1) UU RI tahun 2008 tentang Informasi dan Transaksi Elektronik, dengan ancaman pidana maksimal 6 tahun dan denda satu miliar.

3) $\mathrm{H}$, warga Mamuju $\mathrm{H}$ (32), warga Kota Mamuju, Sulawesi Barat, harus berurusan dengan kepolisian setempat karena unggahan status di akun Facebook bernama Ancha Evus pada 15 Julli 2017. Status yang diberi judul "Martabak Telor" tersebut ditulis H agak panjang hingga banyak pengguna akun Facebook lainnya yang tidak membacanya hingga tuntas. Awalnya, ia bermaksud bercanda dengan status yang dibuatnya itu, dengan menyatakan Kota Mamuju saat ini berstatus siaga 1 lantaran ada kasus mutilasi terhadap Martha. Akibatnya, status tersebut membuat resah warga Mamuju. Perbuatan tersebut dinilai melanggar Undang-undang Nomor 19 tahun 2016 tentang Informasi dan Transaksi Elektronik.

4) A dan $S A$, seorang pegawai negeri sipil, dan $S$, petugas satuan pengamanan pada sebuah perusahaan di Kota Tarakan, Kalimantan Utara, harus berurusan dengan Kepolisian Resor Tarakan karena status yang dinilai menghina Polri dan mengandung konten ujaran kebencian. Status itu diunggah melalui akun Facebook pada 14 Juni 2017. Dalam 
statusnya, A menuliskan keberatannya saat ditilang oleh polisi. Kemudian, $S$ turut berkomentar pada postingan ini. Hal yang dituliskan keduanya pada status A dianggap melecehkan institusi kepolisian.

5) Ahmad Dhani Ahmad Dhani, musisi ibukota ini dilaporkan oleh sebuah kelompok pendukung Ahok-Djarot, yaitu BTP Network terkait dengan penyebaran informasi yang menimbulkan kebencian. Dhani membuat kicauan di akun Twitter pribadinya, @AHMADDHANIPRAST. la dilaporkan pada 9 Maret 2017. Dhani dilaporkan melanggar Pasal 28 ayat (2) juncto Pasal 45 ayat (2) Undang-undang Nomor 19 Tahun 2016 tentang Informasi dan Transaksi Elektronik.

6) MG dilaporkan oleh Wali Kota Baubau, Sulawesi Tenggara, AS Thamrin atas dugaan pencemaran nama baik. Dugaan pencemaran nama baik itu diduga karena unggahan MG melalui akun Facebook-nya. MG mengunggah foto Wali Kota BauBau, AS Thamrin, yang sedang melayat ke rumah warga, dengan posisi duduk di kursi yang telah disediakan. Keterangan dalam foto tersebut membuat AS Thamrin melaporkan MG.

7) Himma Dewiyana, dosen Dosen Universitas Sumatera Utara, Himma Dewiyana Lubis alias Himma (46), ditetapkan polisi sebagai tersangka karena status yang diunggahnya di Facebook. Menurut Himma, status yang diunggah bukan miliknya. la hanya menyebarkan status yang berbunyi, "3 bom gereja di surabaya hanyalah pengalihan isu" Skenario pengalihan yg sempurna. Setelah mengetahui unggahannya viral, Himma langsung menutup akun Facebook-nya. Namun, unggahan itu sudah terlanjur di-screenshoot warganet dan dibagikan ke media daring.

\section{Ancaman hukuman dalam Undang-Undang Informasi dan Transaksi Elektronik.}

Adapun ancaman hukuman yang ada dalam Undang-Undang Republik Indonesia Nomor 19 Tahun 2016 Tentang Perubahan Atas Undang-Undang Nomor 11 Tahun 2008 Tentang Informasi Dan Transaksi Elektronik adalah :

a. Ancaman pelanggaran kesusilaan (Pasal 27 Ayat 1).

b. Penghinaan dan/atau pencemaran nama baik (Pasal 27 Ayat 3).

c. Penyebaran kebencian berdasarkan suku, agama, ras dan antar golongan (SARA) (Pasal 28 Ayat 2).

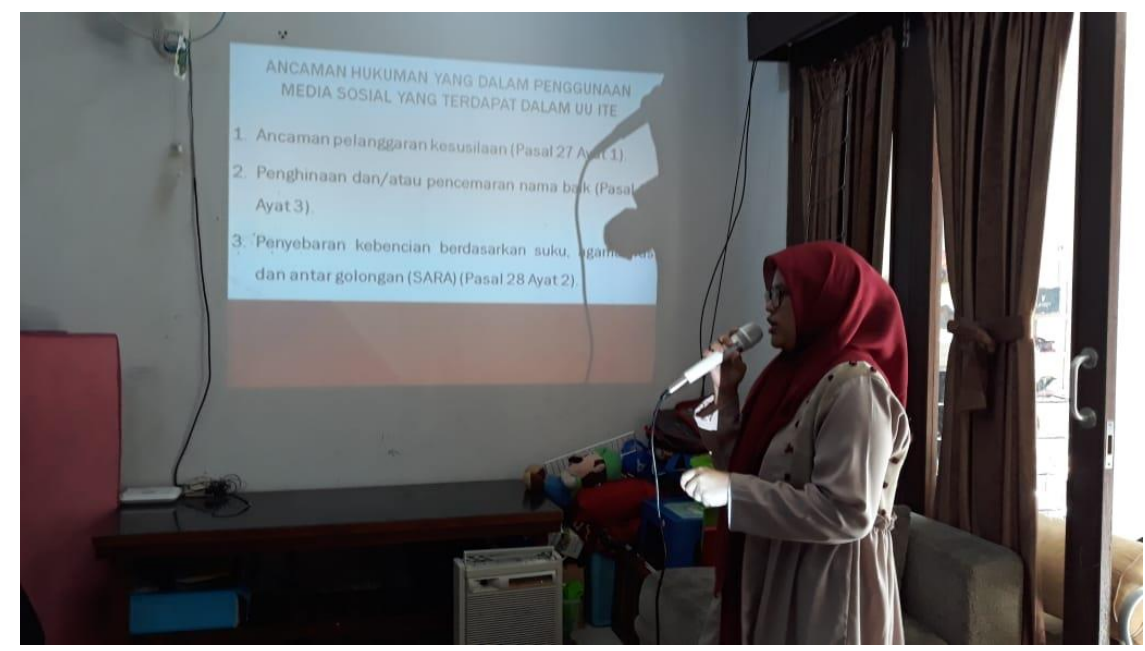

Tim PKM memaparkan Ancaman Hukuman dalam UU ITE 


\section{Tips Menjadi Pengguna Media Sosial yang Cerdas dan Bijak.}

Beberapa tips dalam penggunaan media sosial yang cerdas dan bijak bagi pengguna media sosial adalah :
a. Tidak share info pribadi.
b. Jaga inner circle.
c. Jaga etika.
d. No sara, no hoax.
e. Cantumkan sumber konten.
f. Sarana pengembangan diri.
g. Bangun jaringan.

Setelah menyampaikan materi tentang penggunaan media sosial yang cerdas dan bijak berdasarkan undang-undang informasi dan transaksi elektronik.Tim pengabdian melakukan tanya jawab terhadap peserta PKM mengenai materi yang diberikan untuk melihat apakah materi yang disampaikan dapat diterima oleh peserta dengan baik. Peserta PKM sangat antusias dalam menjawab pertanyaanpertanyaan yang diberikan, dari jawaban peserta PKM, dapat terlihat bahwa metri yang disampaikan dapat dimengerti dan dipahami peserta PKM dengan baik.

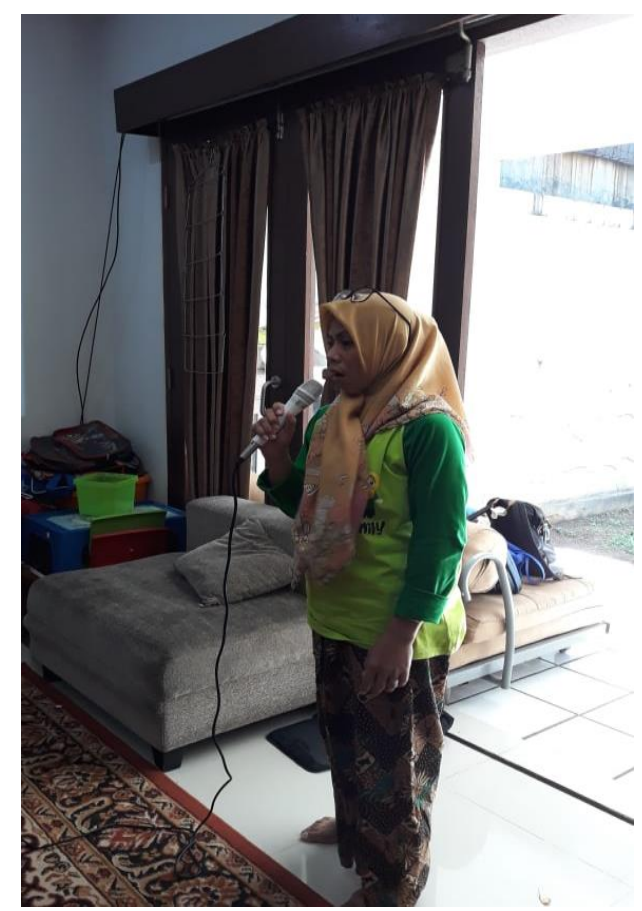

Salah Satu Peserta PKM Yang Menjelaskan Materi Yang Disampaiakan 


\section{HASIL DAN PEMBAHASAN}

Berdasarkan pendampingan yang dilakukan melalui proses berdialog dengan masyarakat sasaran melalui kegiatan pra penyuluhan, setelah itu ditindaklanjuti dengan kegiatan pelatihan dalam bentuk penyuluhan. Setelah dilakukan sosialisai maka diadakan pula pelatihan penggunaan media sosial yang cerdas dan bijak berdasarkan undang-undang informasi dan transaksi elektronik dan pada akhirnya dilaksanakan kegiatan simulasi untuk menguji peningkatan pemahaman para ibu-ibu rumah tangga untuk menjadi pengguna media sosial yang cerdas dan bijak, diperoleh hasil yang menunjukkan bahwa ada peningkatan pemahaman dari peserta dalam penggunaan media sosial. Beberapa pertanyaan yang disampaikan pada saat sebelum pelatihan dan sesudah pelatihan memperlihatkan bahwa peserta sudah mendapatkan pemahaman mengenai :

1. Pengertian Media Sosial.

2. Ciri-Ciri Media Sosial.

3. Kegunaan Media Sosial.

4. Keunggulan Media Sosial dibanding Media Konvensional.

5. Dampak Negatif Media Sosial bagi Keluarga.

6. Undang-Undang Republik Indonesia Nomor 19 Tahun 2016 Tentang Perubahan Atas UndangUndang Nomor 11 Tahun 2008 Tentang Informasi Dan Transaksi Elektronik.

7. Istilah dalam Undang-Undang Informasi dan Transaksi Elektronik.

8. Kasus media sosial yang dibawa ke jalur hukum.

9. Ancaman hukuman dalam Undang-Undang Informasi dan Transaksi Elektronik.

10. Tips Menjadi Pengguna Media Sosial yang Cerdas dan Bijak.

Peningkatan pemahaman ibu rumah tangga terlihat dari jawaban terhadap pertanyaanpertanyaan yang diberikan oleh tim Pengabdian Kepada Masyarakat dalam bentuk quiz, setelah tim menyampaikan materi yang diberikan. Peserta sangat antusias untuk menjawab pertanyaan sesuai dengan apa yang mereka dapatkan dari penyuluhan yang dilakukan oleh tim. Hal ini sudah mencapai target awal yang ditetapkan oleh tim pengabdi. Setalah mendapatkan penyuluhan, peserta pengabdian semakin menyadari bahwa penggunaan media sosial haruslah digunakan sebagaimana tujuannya, pentingnya pemahaman tentang media sosial, akan mengarahkan mereka untuk lebih berhati-hati dalam mengupdate status, berkomentar dan menyebarkan informasi melalui media sosial, karena peserta khawatir jika melakukan hal-hal yang negatif pada penggunaan media sosial akan membawa mereka terjerat ke kasus hukum seperti kasus-kasus hukum yang sudah terjadi yang dipaparkan oleh tim pengabdi sebelumnya.

Perbuatan negatif yang mereka lakukan di media sosial akan dibaca oleh orang lain bahkan mungkin akan ditiru oleh anak anak mereka sendiri.Sebagai ibu rumah tangga mereka sangat menyadari bahwa penggunaan media sosial dalam kehidupan sehari-hari harus lebih membawa banyak dampak positif untuk diri sendiri, lingkungan dan keluarga. Hal ini bisa menghindari mereka dari jerat hukum yang ada di dalam Undang-Undang Informasi dan Transaksi Elektronik.

Adapun kendala dalam pengabdian ini antara lain, waktu yang terlalu singkat untuk penyampaian materi dan proses berdialog serta bebrapa peserta yang izin beberapa menit untuk menjemput anak sekolah dan kembali mengikuti kegiatan ini setelah menjemput anak sekolah. Bentuk pengabdian yang dilakukan terhadap masyarakat sekecil apapun akan memberikan dampak yang luar biasa. Terutama bagi perkembangan dan pemerataan ilmu pengetahuan sebagaimana yang dilakukan oleh tim dalam 
memberikan pengabdian kepada masyarakat di RT.005, Kelurahan Ciganjur, Kecamatan Jagakarsa, Jakarta Selatan.

Pengabdian kepada masyarakat ini, lebih memotivasi peserta untuk menggunakan media sosial ke hal-hal yang positif seperti penyampaian informasi yang jelas yang bermanfaat bagi banyak orang serta tidak menyinggung SARA (dapat membedakan antara berita palsu atau bukan), menggunakan media sosial sebagai alat silaturahmi ke teman dan keluarga serta menggunakan media sosial untuk berjualan secara online untuk kesejahteraan keluarga.

Hasil yang dicapai ini, sesuai dengan tujuan dan harapan dari diadakannya Pengabdian Kepada Masyarakat oleh tim pengabdi dan mitra tim pengabdi yaitu Ketua RT 005, Kelurahan Ciganjur, Kecamatan Jagakarsa, Jakarta Selatan, agar tidak semakin banyak pengguna media sosial yang terjerat ancaman hukuman dalam Undang-Undang Nomor 19 Tahun 2016 tentang Perubahan atas UndangUndang Nomor 11 Tahun 2008 tentang Informasi dan Transaksi Elektronik dalam kehidupan sehari-hari.

\section{SIMPULAN}

Pengabdian Masyarakat ini dilaksanakan di RT.005, Kelurahan Ciganjur, Kecamatan Jagakarsa, Jakarta Selatan sebanyak 20 peserta yaitu ibu rumah tangga. Pengabdian ini mampu menggeser pemahaman dan perilaku ibu rumah tangga dalam penggunaan media sosial agar menjadi pengguna media sosial yang cerdas dan bijak baik untuk dirinya sendiri, keluarga maupun lingkungannya. Selain itu, ibu rumah tangga juga mengetahui ancaman hukuman yang ada dalam Undang-Undang Republik Indonesia Nomor 19 Tahun 2016 Tentang Perubahan Atas Undang-Undang Nomor 11 Tahun 2008 Tentang Informasi Dan Transaksi Elektronik yaitu Ancaman pelanggaran kesusilaan, Penghinaan dan/atau pencemaran nama baik danPenyebaran kebencian berdasarkan suku, agama, ras dan antar golongan (SARA). Hal ini merupakan bentuk langkah preventif sebelum pengguna sosial media dirugikan dari penggunaan media sosial yang tidak sebagaimana mestinya.

Oleh karena itu, kegiatan pengabdian ini telah tepat pada sasaran yang dituju serta memberikan pengetahuan baru terutama terkait ancaman hukuman yang bisa terkena kepada pengguna media sosial apabila tidak digunakan untuk hal-hal yang positif. Peserta menunjukkan ketertarikan dalam kegiatan dengan indikator banyaknya peserta yang terlibat dan antusias untuk menjawab pertanyaan dalam quiz dan proses diskusi setelah dilaksanakannya penyuluhan.

\section{REFERENSI}

Andi Hamzah, 1996, Hukum Pidana Yang Berkaitan Dengan Komputer, Jakarta:Sinar Grafika James R Situmorang, 2012, Pemanfaatan Internet sebagai New Media dalam Bidang Politik, Bisnis, Pendidikan dan Sosial Budaya, "Jurnal Administrasi Bisnis, Volume 8 Nomor 1.

Muhammad Hisyam dan Cahyo Pamungkas, 2016, Indonesia, Globalisasi, dan Global Village, Jakarta: Yayasan Pustaka Obor Indonesia.

Muh Taufik Hafid, 2015, Penegakan Hukum Terhadap Tindak Pidana Melalui Penggunaan Media Sosial di Kota Makassar, Skripsi Bagian Hukum Masyarakat Dan Pembangunan, Fakultas Hukum Universitas Hasanuddin, Makassar.

Soecipto dan Abdul Holik, 2018, Pemanfaatan Media Sosial Bagi Ibu Rumah Tangga dan Pemuda di Desa Arjasari Kecamatan Arjasari Kabupaten Bandung, Jurnal Pengabdian Masyarakat, Volume 8 Nomor 1.

https://www.maxmanroe.com/vid/teknologi/internet/pengertian-media-sosial.html, "Pengertian Media Sosial Secara Umum, Fungsi, Tujuan, Jenis Sosmed". 
https://beritagar.id/artikel/berita/ibu-rumah-tangga-dan-facebook-jerat-empuk-uu-ite,"'lbu rumah tangga dan Facebook, jerat empuk UU ITE”.

https://www.pahlevi.net/pengertian-media-sosial/, "Pengertian Media Sosial, Jenis, Ciri-Ciri dan Fungsi".

https://regional.kompas.com/read/2018/05/21/16462171/7-kasus-status-dimedia-sosial-yangpernah-dibawa-ke-jalur-hukum?page=all, Kompas.com, "7 Kasus Status di Media Sosial yang Pernah Dibawa ke Jalur Hukum"

https://www.popmama.com/life/health/atika-dian/tips-menggunakan-media-sosial-dengan-

bijak/full, "7 Tips menggunakan media sosial dengan bijak". 